DOI: $\underline{10.35619 / \text { iiu.v1i14.410 }}$

Рего Ганна

кандидат педагогічних наук, доцент, доцент кафедри педагогіки та психології Закарпатського інституту післядипломної педагогічної освіти,

м. Ужгород, Україна

ORCID: 0000-0002-6996-2107

e-mail: anna.reho26@gmail.com

Балог Лівія

старший викладач кафедри педагогіки і психології Закарпатського угорського інституту ім. Ференца Ракоці II,

м. Ужгород, Україна

ORCID: 0000-0003-3088-7485

e-mail: baloghlivi1978@gmail.com

\title{
ВИКОРИСТАННЯ ТВОРЧОЇ СПАДЩИНИ \\ В. О. СУХОМЛИНСЬКОГО В ЗАКЛАДАХ ДОШКІЛЬНОЇ ОСВІТИ 3 УГОРСЬКОЮ МОВОЮ НАВЧАННЯ
}

Анотація. Понад сто років ідеї, думки та досвід видатного педагога В. О. Сухомлинського не втрачають своєї значущості, а навпаки, набувають нового звучання в умовах реформування освіти незалежної України та залишаються сучасними й актуальними понині.

Національний склад населення Закарпатської області співвідносний 3 кількістю закладів дошкільної освіти краю. Найбільш поширеною мовою навчання після української $\epsilon$ угорська. Цей факт спонукав нас досліджувати потенціал використання творчої спадщини В. О. Сухомлинського в закладах дошкільної освіти з угорською мовою навчання.

У проведеному дослідженні ми розкриваємо феномен популярності його творів, ефективні засоби впливу на формування особистості дитини дошкільного віку, рекомендовані Василем Сухомлинським, аналізуємо специфіку його творів та рекомендації щодо використання казки у навчально-виховному процесі, вказуючи на шляхи використання їх у роботі з дітьми дошкільного віку угорської національності.

На жаль, складно знайти переклад оповідань та казок В. Сухомлинського угорською мовою. Тільки в 1999 році був виданий збірник «A kék ég alatt» («Під голубим небом»), тож, пізнати чарівність рідної природи й утверджувати прекрасне в собі через повчання великого педагога змогли діти угорської національності на рідній мові. У цих маленьких творах автор розкриває складні поняття зрозумілою для дитини мовою, чим, власне, і формує людську особистість, вчить розуміти, що таке добро і зло, працьовитість та лінь, виховує повагу до старших, любов до

(C) Рего Г., Балог Л., 2021 


\section{Інноватика у вихованні. Випуск 14. 2021.}

рідних та рідного краю, людську гідність, совість тощо. На нашу думку, саме ця специфіка його творів дозволяє ефективно використовувати їх у закладах дошкільної освіти з угорською мовою навчання.

Оскільки в угорській літературі для дітей дошкільного віку є теж багато оповідань та казок, які несуть підтекстову сферу, вважаємо за доцільне добирати схожі за змістом і мораллю казки й оповідання В. О. Сухомлинського та угорські народні чи авторські казки, використовуючи «механізм» педагогічного впливу, який спрямований власне на етичне виховання підростаючого покоління. Такий підхід також $\epsilon$ дійовим засобом навчання дітей угорської національності українській мові.

Ключові слова: казка, оповідання, В. О. Сухомлинський, формування особистості, дитина дошкільного віку, заклад дошкільної освіти 3 угорською мовою навчання.

Постановка проблеми. 28 вересня 2021 року виповнюється 103 роки від дня народження видатного українського радянського педагога, письменника, поета, заслуженого вчителя УРСР, кандидата педагогічних наук, члена-кореспондента Академії педагогічних наук РРФСР, членакореспондента Академії педагогічних наук СРСР Василя Олександровича Сухомлинського. Незважаючи на таку віддаленість у часі, ідеї, думки та досвід видатного педагога набувають нового звучання в умовах реформування освіти незалежної України та залишаються сучасними й актуальними надалі. Його гуманістична педагогіка $€$ особистісноорієнтованою на дитину, за якою вона (дитина) - розглядається як найвища цінність.

Доречно згадати твердження відомого сучасного українського письменника Дмитра Чередниченка: «Якби він не написав жодного літературного твору, а тільки мудрі свої педагогічні праці, все одно залишився б великим письменником. Якби не написав жодної наукової праці, все одно залишився б великим педагогом. А він, на наше щастя, був і великим педагогом, і великим письменником» (Горик-Литвинюк, 2009, с. 23).

Поради і досвід В. О. Сухомлинського живуть і творчо розвиваються в умовах функціонування сучасних закладів дошкільної освіти. Згідно 3 порадам В. Сухомлинського дитина має бути оточена добром та ласкою, повагою та мудрою любов'ю, мати право на власну думку і власну помилку. Тільки тоді підростаюча особистість зможе зробити певні висновки, відчути наслідки своєї поведінки, що в результаті сприятиме формуванню гуманних поглядів на життя та дотриманню гуманістичних принципів у життєвих контактах з оточенням.

Закарпаття унікальна частинка України, де на відносно невеликій території (12 800 км²) (Закарпаття, 2021) проживають представники понад тридцяти національностей. Домінуючим та корінним населенням $\epsilon$ українці (80,5 \%). Проживають також угорці $(12,1 \%)$, румуни $(2,6 \%)$, 


\section{Інноватика у вихованні. Випуск 14. 2021.}

росіяни $(2,5 \%)$, цигани $(1,1 \%)$, словаки $(0,5 \%)$, німці $(0,3 \%)$ та інші (Населення Закарпатської області, 2021). Національний склад населення Закарпатської області співвідносний 3 кількістю закладів дошкільної освіти краю. 3 п’ятсот 595-ти закладів дошкільної освіти за мовами виховання дітей розподілені так: 477 - українською мовою, три румунською мовою, 76 - угорською мовою та 39 кількома мовами (Гриник, 2020 , с.28). Як бачимо, найбільш поширена меншина угорці мають найбільшу кількість закладів дошкільної освіти 3 материнською мовою навчання. Цей факт спонукає нас досліджувати потенціал використання творчої спадщини В. О. Сухомлинського в закладах дошкільної освіти 3 угорською мовою навчання та виховання.

Аналіз останніх досліджень 3 проблеми. Проблема формування дитячої особистості засобами художнього слова В. О. Сухомлинського відображена в працях I. Баранюк, Г. Бондаренко, М. Вашуленко, О. Вознюка, М. Дубинки, О. Макаренко, Л. Мамчур, М. Масловської, О. Монке, Н. Побірченко, О. Соколовської, Л. Старикової, О. Сухомлинської, О. Углової та інших вчених. Незважаючи на велику кількість досліджень, що спрямовані на використання творчої спадщини В. О. Сухомлинського, потенціал використання його творчості в закладах дошкільної освіти 3 угорською мовою навчання залишився за межами уваги науковців.

Мета статті - розкрити потенціал використання творчої спадщини В. О. Сухомлинського в закладах дошкільної освіти з угорською мовою навчання.

Виклад основного матеріалу дослідження. Беззаперечним $є$ той факт, що серед українських дітей, батьків, педагогів Василь Сухомлинський має великий авторитет і як педагог-новатор, і як автор літературних творів для дітей. Феномен популярності його творів полягає в тому, що в них закладено спроможність пробудити в дитини любов до природи, людей, прагнення до знань, моральної та естетичної краси (Павленко, 2020, с.47). Серед педагогів-дошкільників Закарпаття також немає жодного, хто б не був знайомий з творчістю великого педагога. Проведене нами вибіркове опитування слухачів курсів підвищення кваліфікації вихователів закладів дошкільної освіти в Закарпатському інституті післядипломної педагогічної освіти підтверджує, що в закладах дошкільної освіти Закарпаття педагоги активно використовують його творчу спадщину. У зв'язку зі специфікою розвитку дітей дошкільного віку, їх психологічними особливостями педагоги ретельно добирають засоби, методи та форми роботи з ними. Серед ефективних засобів впливу на формування особистості дитини виділяють казку, оповідання, малі фольклорні жанри тощо. Як стверджував сам В. Сухомлинський (1973, с. 26) «Казка, фантазія - це ключик, за допомогою якого можна відкрити джерела думки і слова. Без казки, без гри уяви дитина не може жити... Казка - це образно кажучи, свіжий вітер, що роздмухує вогник дитячої думки і мови». 


\section{Інноватика у вихованні. Випуск 14. 2021.}

Оскільки прижиттєвих видань літературних творів В. Сухомлинського (казок, оповідань, притч, замальовок з життя дітей) не було, зараз важко вказати їх точну кількість. Тільки через вісім років після смерті в Україні вийшла його перша прозова книжка. Проте нині вже видрукувано близько 1500 творів письменника-педагога, які стали окрасою дитячої літератури (Горик-Литвинюк, 2009).

Ще у 1999 році на замовлення управління освіти та науки Закарпатської облдержадміністрації (нині Департамент освіти і науки Закарпатської обласної державної адміністрації) та Закарпатського інституту методики навчання й виховання підвищення кваліфікації педагогічних кадрів (нині Закарпатський інститут післядипломної педагогічної освіти) був виданий переклад оповідань та казок В. Сухомлинського на угорську мову. Збірник розрахований на вчителів та вихователів для читання дітям дошкільного та молодшого шкільного віку угорської національності. Збірник був виданий тиражем 2500 примірників і потрапив у всі школи та дошкільні заклади з угорською мовою навчання. Отже, пізнати чарівність рідної природи й утверджувати прекрасне в собі через повчання великого педагога змогли діти угорської національності на рідній мові.

Погоджуємося 3 автором публікації «Світ казок Василя Сухомлинського у сучасному інформаційному просторі України» Лесею Сухомлинською, що, аналізуючи велику творчу спадщину педагога, нині найбільш затребуваним, найбільш актуальним із усього того, що він нам залишив, є його художня спадщина, тобто казки, оповідання, притчі, новели, етюди, бувальщини, есе (Сухомлинська, 2018, с.16). Хоча всі вони різноманітні за змістом, проте мають спільні характеристики: вони невеликі за обсягом, виважені, наближені до дитячого світосприйняття i, звичайно, розвивальні або ж виховні за спрямуванням. У цих маленьких творах автор розкриває складні поняття зрозумілою для дитини мовою, чим, власне, і формує людську особистість, вчить розуміти, що таке добро і зло, працьовитість та лінь, виховує повагу до старших, любов до рідних та рідного краю, людську гідність, совість тощо. У 2016 році побачила світ унікальна за змістом і найповніша за обсягом на сьогодні збірка творів для дітей Василя Сухомлинського «Я розповім вам казку... Філософія для дітей» (близько 1500 творів автора), яку уклала з усіх доступних наразі джерел донька великого педагога Ольга Сухомлинська (Сухомлинський, 2016).

Специфікою творів В. Сухомлинського $\epsilon$ його дворівневість художньо-педагогічного тексту. Перший рівень - це внутрішній світ твору, сприймаючи який, дитина ніби «входить» у цей світ і починає жити в його атмосфері, а другий - його підтекстова сфера, що є одним із генераторів художньої енергії (Баранюк, 2015, 113-114). Розкодований дитиною смисл входить у їі свідомість і вже стає її смислом, складовою іiї духовного життя, тож, переживаючи почуте, дитина здобуває життєвий досвід, розвиває свої 


\section{Інноватика у вихованні. Випуск 14. 2021.}

емпатичні можливості, інтерес до зображуваних у художньому світі подій, предметних реалій тощо.

Як стверджує дослідниця творчої спадщини В. Сухомлинського Ірина Баранюк (2015, с.113), саме «у поєднанні в художньому світі твору цих двох складових - доступності для дитячого сприймання та наявності підтекстової сфери, яка потребує декодування, - криється один 3 найголовніших «секретів» впливовості творів художньої педагогіки В. Сухомлинського».

На нашу думку, саме ця специфіка дозволяє ефективно використовувати твори В. Сухомлинського в закладах дошкільної освіти 3 угорською мовою викладання. Оскільки, найбільш поширений жанровий різновид оповідань В. Сухомлинського - це мініатюрні новели та казки, сюжет яких складається 3 одного або ж кількох епізодів-картин, що стосуються вчинку дитини або героя новели чи казки, тож вони доступні дітям дошкільного віку. Як правило, в цих творах зображений певний вчинок, що містить у собі підтекстовий смисл, розкриття якого само собою наділене виховним ефектом. В угорській літературі для дітей дошкільного віку $є$ теж багато оповідань та казок, які мають підтекстову сферу. Вважаємо за доцільне підбирати схожі за змістом та мораллю казки і оповідання В. Сухомлинського та угорські народні чи авторські казки, використовуючи «механізм» педагогічного впливу, що спрямований власне на етичне виховання підростаючого покоління.

Наприклад, як оповідання «Іменинний обід (Іменини)» B.Сухомлинського, так і угорська казка «Mese a családról és a fatányérról» («Казка про сім’ю та дерев’яну тарілку») формують у дітей шанобливе ставлення до старших, підводить дітей до розуміння, що не можна поводитися з іншими так, як ти не хочеш, щоб поводилися 3 тобою.

Оповідання «Іменинний обід (Іменини)» В. Сухомлинського закінчується так: «Не сказавши жодного слова, вона зняла зі столу білу скатертину і сховала ї̈ в шафу. Довго сиділа мовчки, потім сказала:

- У нас сьогодні бабуся хвора. Тому іменинного обіду не буде. Поздоровляю тебе, Ніно, з днем народження. Моє тобі побажання: будь справжньою людиною».

Аналогічна за підтекстом казка «Mese a családról és a fatányérról» («Казка про сім’ю та дерев’яну тарілку»), в якій розповідається як неправильні дії сина та невістки щодо дідуся спровокували вчинок дитини - виготовлення дерев'яної тарілки, аби тоді, коли вони постаріють, дати їм iii для користування. Висновок, так само, як i в оповіданні В. Сухомлинського, прихований в закінченні твору: «Hіхто не сказав нічого, але обоє знали, щзо потрібно зробити. Ввечері чоловік взяв дідуся за руку $і$ дуже ніжно повів до сімейного столу. Після цүього, до кінця свого життя дідусь їв разом з усіма за сімейним столом. 3 незрозумілої причини відтоді, ані чоловіка, ані жінку більше не цікавило, щуо впала виделка, чи вилилося молоко, чи їжа забруднила чисту скатертину». 


\section{Інноватика у вихованні. Випуск 14. 2021.}

До прикладу, наведемо ще казку Василя Сухомлинського «Як Миколка став хоробрим» та угорську казку «Peti itatja az egereket» («Петі поїть мишей»). Обидві казки спрямовані на виховання в дітей дошкільного віку хоробрості як риси характеру.

У казці В. Сухомлинського Миколка переборов свій страх, щоб дівчатка не вважали його боягузом: «Вiд страху в нього тремтіли руки й ноги, але він ліз усе вище й вище. Поклав Миколка пташеня в гніздо, а сам спустився додолу. Дівчатка дивилися на нього захоплено».

У казці «Петі поїть мишей» хлопчик переборов свій страх, щоб діти в садочку з нього не глузували: «Направду, Петі трохи боявся, але підняв маленьку тваринку на подив всім. Вихователька теж здивовано дивилася на це дійство, потім сказала:

- Я я не думала, щзо ти такий сміливий. Діточки, дивіться, серед нас є справжній герой, який не боїться мишей. Швиденько просіть від нього пробачення за те, щчо ви його висміювали!».

Можна дібрати багато подібних творів. Проте, обираючи твори для читання дітям дошкільного віку, слід пам'ятати, що яким би важливим не був вплив літературного твору (морально-етичне виховання, звеличення праці, виховання любові до природи тощо), він стає можливий тільки тоді, якщо художній твір сприймається душею дитини, ії̈ власними почуттями. Як писав В. Сухомлинський, «Слово - перша іскра, що запалює факел, який освітлює світ прекрасного» (Горик-Литвинюк, 2009, с.25). Сила літературних творів В.Сухомлинського в тому, що в них акумульовані виховні кодекси, які своєрідно діють на дитячу психіку і свідомість. Оскільки повчання в них не явне, а приховане, дитина не помічає цього впливу, з легкістю ототожнюе себе 3 головними героями і робить відповідні висновки. У казках та оповіданнях автор пропонує дитині образи, символи, які ій подобаються, і при знайомстві з ними вона непомітно для себе засвоює важливу інформацію (Петренко, 2009, с. 426).

Як твердить Г. Бєлєнька $(2018$, с.18), казки В. О. Сухомлинського наповнені змістом і філософією, що впливають на інтелектуальну, емоційну та моральну сфери дитини і спрямовані на формування повноцінної особистості, здатної діяти згідно із загальнолюдськими моральними цінностями. «Добра людина не падає з неба, іiі потрібно виховувати», - наголошував В. О. Сухомлинський (Чернега, 2009, с. 4). Ці слова слід пам'ятати педагогам та батькам дітей дошкільного та молодшого шкільного віку.

Для педагогів, які працюють з дітьми угорської національності, відомим $\epsilon$ ім'я угорського письменника Ервіна Лазара, який здобув популярність завдяки своїм казкам та оповіданням для дітей. Вважаємо за доречне планувати заняття з дітьми дошкільного віку на основі порівняння казок та оповідань Василя Сухомлинського та Ервіна Лазара, шукаючи спільне в їх творчості. У такий спосіб, відбуватиметься наближення угорських дітей до творчості В. Сухомлинського. 


\section{Інноватика у вихованні. Випуск 14. 2021.}

Випереджувальні на той час були теоретично обгрунтовані рекомендації В. Сухомлинського про необхідність та значущість виховання у дітей почуття справедливості, совісті, сорому, щедрості, милосердя тощо, переконання в тому, що діти повинні навчитися давати оцінку своїм вчинкам та вчинкам інших людей (Чепіль, 2012, с. 37). Ці ідеє $\epsilon$ дуже актуальними на сьогоднішній день. У творах, написаних для дітей, В. Сухомлинський уміло малює контраст краси і потворності, ставить слухача перед дилемою вибору так, що вибрати потворність - неможливо. Завдяки осмисленню цих творів, у дитини формуються сталі навички поведінки, які вона переноситиме в повсякденне життя.

Читаючи твори Василя Олександровича, відчуваємо, що всі вони пронизані популярними в сучасній педагогіці ідеями позитивної «Яконцепції». В. Сухомлинський виділяв надзвичайний вплив ситуації успіху на розвиток дитини та на формуванні ії самооцінки. Великий педагог переконаний, «що найважливіше... це зміцнювати у дитини віру в свої сили і терпляче чекати того моменту, коли відбудеться хоча б маленьке зрушення в ії розумовій праці... Зрушення це, по суті, дуже маленьке. На перший погляд воно може видатися просто випадковою удачею. Але цю удачу дитина переживає як радісний успіх - у цьому успіху вона черпає нову енергію». (Сухомлинський, 1976. с.391). Завдання умілого педагога полягає в тому, щоб дитина ніколи не втратила віру у свої сили, ніколи не відчула, що в неї нічого не виходить.

Батькам дітей дошкільного віку доречно прислухатися до порад великого педагога, який був переконаний: те, що важко передати звичайними словами, можна передати за допомогою літературного твору, й, найперше, через казку.

Не втрачають своєї актуальності в роботі 3 дітьми угорської національності поради В. О. Сухомлинського щодо використання казки у навчально-виховному процесі.

Основними формами роботи 3 казкою, запропонованими В. Сухомлинським $є$ :

слухання казок;

читання казок;

бесіди за змістом казки;

виготовлення і добір ілюстрацій до казок;

інсценізація казок (театралізація);

творення казок (Заліток, 2012, с. 116).

Такий підхід $\epsilon$ дійовим засобом навчання дітей угорської національності українській мові, оскільки, «через казкові образи в свідомість дітей входить слово з його найтоншими відтінками; воно стає сферою духовного життя дитини, засобом висловлення думок і почуттів» (Сухомлинський, 2016, с.19.).

У закладах дошкільної освіти з угорською мовою навчання доречно використовувати збірки художніх мініатюр В. Сухомлинського: «Чиста криниця» (1993), «Вічна тополя» (2002), «Вогнегривий коник» (2008, 


\section{Інноватика у вихованні. Випуск 14. 2021.}

2016), «Квітка сонця» (2009), «Всі добрі люди - одна сім’я» (2009) та ін. У багатій педагогічній спадщині В. Сухомлинського педагоги можуть знайти матеріал для використання з будь-якою навчально-виховною метою.

М. Масловська (2002, с.216) влучно підкреслила, що «особливістю поетики казок В. Сухомлинського $є$ захоплююча майстерність творення простих, на перший погляд, казок та оповідань: вони не перевищують 150 слів, але яким треба бути великим майстром, аби в таку малу кількість слів вкласти таку високу якість думки, повчання». Цей малий за розміром художній твір має глибоку філософію i величезний педагогічний потенціал, спонукаючи до розмірковувань і висновків, призводить в дію активну педагогіку.

Висновки і перспективи подальших розвідок. Оскільки читання казок та оповідань В.Сухомлинського займає зовсім небагато часу, рекомендуємо використовувати їх у роботі з дітьми дошкільного віку, які навчаються угорською мовою, як під час занять, так і в повсякденному житті. Це стане основою розвитку спостережливості, естетичних смаків, екологічного мислення, природоохоронної діяльності дітей дошкільного віку та сприятиме міцному й глибокому усвідомленню навчальновиховного матеріалу. Діючи одночасно і на розум, і на почуття дитини, лаконічні за змістом твори розвивають ії інтелект та емоційність на рівні свідомості та підсвідомості, допомагають пояснити дітям життєві істини у легкій та доступній формі.

Перспективним напрямом у подальшому вивченні освітнього потенціалу казок i оповідань малої художньої прози Василя Сухомлинського $є$ дослідження шляхів їх використання під час навчання дітей угорської національності українській мові.

\section{СПИСОК ВИКОРИСТАНИХ ДЖЕРЕЛ}

Горик-Литвинюк, Н. (2009). Виховання естетичних почуттів засобами художнього слова В.О.Сухомлинського. В: Збірник науково-методичних праць викладачів та студентів Луиьького педагогічного коледжу (Випуск 2). Луцьк: Луцький педагогічний коледж, с.23-30.

Загальна площа Закарпаття. URL: https://uk.wikipedia.org/wiki/Закарпаття [Дата звернення 02.09.2021].

Населення Закарпатської області. Режим доступу: https://uk.wikipedia.org/wiki/Населення_Закарпатської_області [Дата звернення 02.09.2021].

Гриник, Г. (2020). Діяльність закладів освіти у Закарпатській області. Ужгород: Головне управління статистики у Закарпатській області, 131 с.

Павленко, Ю. (2020). Феномен педагогічної казки Василя Сухомлинського. Науково-педагогічні студії, (4). Режим доступу: https://doi.org/10.32405/2663-5739-2020-4-45-53 [Дата звернення 02.09.2021].

Сухомлинський, В. (1973). Серце віддаю дітям. Вибрані твори: в 5 m. Т. 3. Київ: Рад. школа, с. 26.

Сухомлинська, Л. (2018). Світ казок Василя Сухомлинського у сучасному інформаційному просторі України. Педагогічна освіта: Теорія $i$ практика. Психологія.

Педагогіка.,

(29),

16-21.

URL: 


\section{Інноватика у вихованні. Випуск 14. 2021.}

https://pedosvita.kubg.edu.ua/index.php/journal/article/view/256 [Дата звернення 02.09.2021].

Сухомлинський, В. (2016). Я розповім вам казку... Філософія для дітей / уклад. О. Сухомлинська. Харків: Школа, 2016. 576 с.

Баранюк, I. (2015). Поетика творів художньої педагогіки В.Сухомлинського. Наукові записки Серія: Педагогічні науки. 123(I), с.112-116.

Казки Василь Сухомлинський «Іменинний обід (Іменини)». UKR: http://abetka.ukrlife.org/sukhom75.html [Дата звернення 03.09.2021].

Mese a családról és a fatányérról. URL: http://fokk.hu/hu/blogs/read/1QlIn/Mese+ [Дата звернення 03.09.2021].

Казки Василь Сухомлинський «Як Миколка став хоробрим». URL: http://abetka.ukrlife.org/sukhom121.html [Дата звернення 02.09.2021].

Peti itatja az egereket. URL: https://meseorszag1.webnode.hu/meseim/ [Дата звернення 03.09.2021].

Петренко, О. (2009). Роль казки у формуванні орієнтації дитини на цінності своєї статі (на матеріалі спадщини Василя Сухомлинського). В: Збірник наукових праць: Педагогічні науки. (53). с. 430.

Бєлєнька, Г., Рухницька, П. (2018). Роль казок В. О. Сухомлинського в процесі виховання морально-етичних якостей дітей старшого дошкільного віку. Молодий вчений. 8.1 (60.1). с.18-21.

Чернега, Н. (2009). Морально-етичне виховання дітей дошкільного віку. Адаптована програма щодо морально-етичного виховання дітей дошкільного віку. Сквира: Джерело, 2009. 40 с.

Чепіль, М. (2012). Ідея добра і любові у педагогічній спадщині Василя Сухомлинського. К.: Молодь і ринок, 2012. (1). с. 176.

Сухомлинський, В. (1976). Вибрані твори. В 5-ти m. (Т.4). Київ: Рад.школа. c.391.

Заліток, Л. (2012). В.О. Сухомлинський про роль казки у вихованні та навчанні дітей $з$ особливими потребами. Актуальні проблеми навчання та виховання людей з особливими потребами. (9). с. 233.

Масловська, М. (2002). Казковий світ Василя Сухомлинського. ВолиньЖитомирщчина. Історико-філологічний збірник з регіональних проблем, (9). с. 215219.

\section{REFERENCES}

Horyk-Lytvyniuk, N. (2009). Vykhovannia estetychnykh pochuttiv zasobamy khudozhnoho slova V.O.Sukhomlynskoho [Education of aesthetic feelings by means of the artistic word of V.O. Sukhomlinsky]. B: Zbirnyk naukovo-metodychnykh prats vykladachiv ta studentiv Lutskoho pedahohichnoho koledzhu (Vypusk 2). Lutsk: Lutskyi pedahohichnyi koledzh, s.23-30. [in Ukrainian].

Zahalna ploshcha Zakarpattia [The total area of Transcarpathia]. URL: https://uk.wikipedia.org/wiki/Закарпаття [Data zvernennia 02.09.2021]. [in Ukrainian].

Naselennia Zakarpatskoi oblasti [The population of the Transcarpathian region]. URL: https://uk.wikipedia.org/wiki/Населення_Закарпатської області [Data zvernennia 02.09.2021]. [in Ukrainian].

Hrynyk, H. (2020). Diialnist zakladiv osvity u Zakarpatskii oblasti [Activities of educational institutions in the Transcarpathian region]. Uzhhorod: Holovne upravlinnia statystyky u Zakarpatskii oblasti, $131 \mathrm{~s}$. [in Ukrainian].

Pavlenko, Yu. (2020). Fenomen pedahohichnoi kazky Vasylia Sukhomlynskoho [The phenomenon of Vasyl Sukhomlynsky's pedagogical fairy tale]. Naukovo- 


\section{Інноватика у вихованні. Випуск 14. 2021.}

pedahohichni studii, (4).URL: https://doi.org/10.32405/2663-5739-2020-4-45-53 [Data zvernennia 02.09.2021]. [in Ukrainian].

Sukhomlynskyi, V. (1973). Sertse viddaiu ditiam [I give my heart to children]. Vybrani tvory: $v 5$ t. T. 3. Kyiv: Rad. shkola, s. 26. [in Ukrainian].

Sukhomlynska, L. (2018). Svit kazok Vasylia Sukhomlynskoho u suchasnomu informatsiinomu prostori Ukrainy [The world of Vasyl Sukhomlynsky's fairy tales in the modern information space of Ukraine]. Pedahohichna osvita: Teoriia i praktyka. Psykholohiia. Pedahohika, (29), 16-21. URL: https://pedosvita.kubg.edu.ua/index.php/journal/article/view/256 [Data zvernennia 02.09.2021]. [in Ukrainian].

Sukhomlynskyi, V. (2016). Ya rozpovim vam kazku... Filosofiia dlia ditei [I will tell you a fairy tale... Philosophy for children]./ uklad. O. Sukhomlynska. Kharkiv: Shkola, 2016. $576 \mathrm{~s}$.

Baraniuk, I. (2015). Poetyka tvoriv khudozhnoi pedahohiky V.Sukhomlynskoho [Poetics of works of art pedagogy of V. Sukhomlinsky]. Naukovi zapysky Seriia: Pedahohichni nauky. 123(I), s.112-116. [in Ukrainian].

Kazky Vasylya Sukhomlynskoho "Imenynnyi obid (Imenyny” [Tales by Vasyl Sukhomlynskyi "Birthday Lunch (Birthdays)"]. URL: http://abetka.ukrlife.org/sukhom75.html [Data zvernennia 03.09. 2021]. [in Ukrainian].

Mese a csaladrol es a fatanyerrol [A tale about the family and the wooden plate]. URL : http://fokk.hu/hu/blogs/read/1QlIn/Mese+ [Data zvernennia 03.09.2021]. [in Hungarian].

Kazky Vasylia Sukhomlynskoho "Yak Mykolka stav khorobrym” [Tales by Vasyl Sukhomlynskyi "How Mykolka Became Brave"]. URL: http://abetka.ukrlife.org/sukhom121.html [Data zvernennia 02.09.2021]. [in Ukrainian].

Peti itatja az egereket [Peti gives to drink to the mouses]. URL: https://meseorszag1.webnode.hu/meseim/ [Data zvernennia 03.09.2021]. [in Hungarian].

Petrenko, O. (2009). Rol kazky u formuvanni oriientatsii dytyny na tsinnosti svoiei stati (na materiali spadshchyny Vasylia Sukhomlynskoho) [The role of a fairy tale in the formation of a child's orientation to the values of his sex (on the material of Vasyl Sukhomlynskyi's herritage)]. Zbirnyk naukovykh prats: Pedahohichni nauky. (53). s. 430. [in Ukrainian].

Bielienka, H., Rukhnytska, P. (2018). Rol kazok V.O. Sukhomlynskoho v protsesi vykhovannia moralno-etychnykh yakostei ditei starshoho doshkilnoho viku [The role of fairy tales V.O. Sukhomlinsky in the process of educating the moral and ethical qualities of older preschool children]. Molodyi vchenyi. 8.1 (60.1). s.18-21. [in Ukrainian].

Cherneha, N. (2009). Moralno-etychne vykhovannia ditei doshkilnoho viku [Moral and ethical education of preschool children]. Adaptovana prohrama shchodo moralnoetychnoho vykhovannia ditei doshkilnoho viku. Skvyra: Dzherelo, 2009. 40 s. [in Ukrainian].

Chepil, M. (2012). Ideia dobra i liubovi u pedahohichnii spadshchyni Vasylia Sukhomlynskoho [The idea of goodness and love in the pedagogical heritage of Vasyl Sukhomlynsky]. K.: Molod i rynok, 2012. (1). s. 176. [in Ukrainian].

Sukhomlynskyi, V. (1976). Vybrani tvory. V 5-ty t. [Selected works. In the 5. T.] (T.4). Kyiv: Rad.shkola. s.391. [in Ukrainian].

Zalitok, L. (2012). V.O. Sukhomlynskyi pro rol kazky u vykhovanni ta navchanni ditei z osoblyvymy potrebamy [V.O. Sukhomlinsky on the role of fairy tales in the education and training of children with special needs]. Aktualni problemy navchannia ta vykhovannia liudei z osoblyvymy potrebamy. (9). s. 233. [in Ukrainian]. 


\section{Інноватика у вихованні. Випуск 14. 2021.}

Maslovska, M. (2002). Kazkovyi svit Vasylia Sukhomlynskoho [The fairy-tale world of Vasyl Sukhomlynsky]. Volyn-Zhytomyrshchyna. Istoryko-filolohichnyi zbirnyk z rehionalnykh problem, (9). s. 215-219. [in Ukrainian].

\section{THE USE OG THE CREATIVE HERITAGE OF V. O. SUKHOMLYNSKYI IN PRESCHOOL EDUCATIONAL INSTITUTIONS WITH THE HUNGARIAN LANGUAGE OF TEACHING}

Hanna Reho

Candidate of Pedagogical Sciences, Associate Professor, Associate Professor at the Department of Pedagogy and Psychology, Transcarpathian Institute of Postgraduate Pedagogical Education,

Uzhhorod, Ukraine

ORCID: 0000-0002-6996-2107 e-mail: anna.reho26@gmail.com

Livia Balogh

Senior Lecturer at the Department of Pedagogy and Psychology, Ferenc Rakoczi II Transcarpathian Hungarian Institute, Uzhhorod, Ukraine ORCID: 0000-0003-3088-7485 e-mail: baloghlivi1978@gmail.com

Abstract. Over a hundred years, the ideas, thoughts and experience of the outstanding teacher V. O. Sukhomlynskyi do not lose their significance, but on the contrary, receive new spin on in the context of reforming the education of independent Ukraine and remain modern and relevant to this day.

The ethnic composition of the population of Zakarpattia oblast is correlated with the number of preschool education institutions in the region, therefore, after Ukrainian as the language of teaching - the most common is Hungarian. This fact encouraged us to explore the potential of using the creative heritage of V.O. Sukhomlynskyi in preschool institutions with Hungarian as the language of teaching.

In this publication, we reveal the phenomenon of popularity of his works; effective means of influencing the formation of the personality of a preschool child, recommended by V. Sukhomlynskyi; we analyze the specifics of his works and recommendations to use of fairy tales in the educational process, pointing to ways to use them in working with preschool children of Hungarian nationality.

Unfortunately, it is difficult to find a translation of V. Sukhomlynskyi's stories and fairy tales into Hungarian. Only in 1999, the collection "A kék ég alatt" ("Under the Blue Sky") was published, so that children of Hungarian nationality could learn the charm of native nature and assert the beauty inside them through the teachings of a great teacher in their native language. In these small works, the author reveals complex concepts in a language that is understandable to the child, which, in fact, forms a human personality, teaches 


\section{Інноватика у вихованні. Випуск 14. 2021.}

to understand what is good and evil, hard work and laziness, cultivates respect for elders, love for family and homeland, human dignity, conscience, etc. In our opinion, it is this specificity of his works that allows them to be used effectively in preschool educational institutions with Hungarian as the language of teaching.

Since in Hungarian literature for preschool children there are also many stories and tales with implied sense, we consider it appropriate to select similar in content and moral tales and stories of V. Sukhomlynskyi and Hungarian folk or author's tales, using the "mechanism" of pedagogical influence, which is aimed at the ethical education of the younger generation. This approach will be an effective means of teaching Hungarian children the Ukrainian language.

Keywords: fairy tale, short story, V. Sukhomlynskyi, personality formation, preschool child, preschool education institution with Hungarian as the language of teaching.

Стаття надійшла до редакиії 04.10.2021p. 